\title{
On the scope and grounds of social equality
}

\author{
REKHA NATH
}

\subsection{Introduction}

In a globally interdependent world, the lives of individuals who belong to different states are connected in many ways. Bangladeshi workers in the garment industry sew clothes sold by an American company to Australian consumers. The Canadian agricultural sector relies on labor supplied by Jamaican and Mexican seasonal migrant workers. Fishermen from Southeast Asia may find that they no longer have a market for their catch because their nets fail to meet the latest environmental standards set by the European Union. Indian generic drug manufacturers are forced to close down operations due to changes in international intellectual property rights regulations, and this in turn results in many Malaysian citizens losing access to previously affordable medicines.

Rich and powerful nations disproportionately influence the terms of global interaction, which has led to the emergence of a set of rules, norms, and practices that are largely skewed to favor the interests of those in wealthier nations. ${ }^{1}$ It is clear that the social and economic gains of interaction between foreigners are not evenly spread. To be sure, many sweatshop workers and migrant laborers have access to vastly superior opportunities than they would have in the absence of cross-border arrangements. But their gains are miniscule when compared to the huge profits reaped by their well-off foreign employers. And despite any material gains they might enjoy, immigrants from developing nations often find themselves socially and culturally marginalized in the countries in which they take up residence.

Is the unequal character of the terms that characterize the political, social, and economic interaction between foreigners morally problematic? The inegalitarian relations between individuals from different states might be criticized for contributing to the perpetuation of severe deprivation on a global scale. ${ }^{2}$ And having that effect would provide a compelling reason for regarding those unequal relations as problematic. However, the main issue I explore in this essay is whether there is a distinctively egalitarian reason for objecting to such relations (that is, a reason that fundamentally concerns the unequal character of these

\footnotetext{
${ }^{1}$ See, for instance, Thomas Pogge, Politics as Usual: What Lies Behind the Pro-poor Rhetoric. (Cambridge: Polity Press, 2010). I use the term "foreigners" to refer to individuals who are not citizens of the same state, even if they happen to reside in the same state.

2 See Pogge's development of this argument in his "Why Inequality Matters," in Global Inequality: Patterns and Explanations, eds. David Held and Ayse Kaya, (Cambridge: Polity Press, 2007), 132-47.
} 
relations) that arises even in cases in which none of the individuals involved live in conditions of severe deprivation. And, relatedly, I consider how, if at all, such unequal relations between foreigners ought to be addressed if they turn out to be problematic for that reason.

One might expect both of those issues to be addressed in the recent literature on social equality. On social equality, relationships ought to be structured on egalitarian terms. ${ }^{3}$ But in this literature, these issues are rarely discussed in much depth. Instead, discussion of social equality has tended to focus on assessing how well this view captures that which is centrally valuable about equality, as compared to rival accounts of egalitarianism. ${ }^{4}$ The issue of the scope of social equality - that is, between whom, or in the context of which relationships, demands of social equality arise - has received little significant attention. ${ }^{5}$ The scope issue in turn depends on the further issue of the grounds of social equality - that is, the basis upon which demands of social equality arise between particular parties. The latter issue has received even less attention than the former. In this essay I aim to address these relatively neglected issues.

I argue that if demands of social equality can arise between fellow citizens, then they can arise between foreigners. The basis for that conditional conclusion is relatively simple. Demands of social equality can arise between fellow citizens for certain reasons. Analogous reasons justify drawing analogous conclusions in cases in which the individuals whose relations are the object of moral assessment belong to different states. When we scrutinize the considerations that social egalitarians advance for concluding that demands of social equality arise in the state, it becomes plausible that underlying those considerations are morally relevant facts that can obtain (and, in fact, do seem to obtain) beyond state borders. Thus, my argument suggests an account of the grounds of social equality, and this account provides support for taking the scope of social equality to potentially transcend the state.

I proceed as follows. In section 9.2, I consider the basis upon which demands of social equality seem to arise between fellow citizens. In section 9.3, I explain why it might appear that no such demands could arise with respect to relations between foreigners. In sections 9.4

\footnotetext{
${ }^{3}$ Important discussions of social equality include the following: Elizabeth Anderson, "What Is the Point of Equality?" Ethics 109 (1999): 287-333; David Miller, "Equality and Justice," in Ideals of Equality, ed. Andrew Mason, (Oxford: Blackwell, 1998), 21-36; Martin O’Neill, "What Should Egalitarians Believe?" Philosophy \& Public Affairs 36, no. 2 (2008): 119-156; T. M. Scanlon, "The Diversity of Objections to Inequality," in The Ideal of Equality, ed. Matthew Clayton and Andrew Williams (Basingstoke: Palgrave Macmillan, 2002), 41-59; and Samuel Scheffler, Equality and Tradition: Questions of Value in Moral and Political Theory (Oxford: Oxford University Press, 2010), chs. 7 and 8.

${ }^{4}$ This focus seems justified given the dominant position these rival accounts have occupied in contemporary debates about the nature and value of equality. See, for instance, Anderson, "What Is the Point of Equality?" and Scheffler, Equality and Tradition, chs. 7 and 8, especially p. 229n26.

${ }^{5}$ For some discussion of the scope issue, however, see Charles Beitz, "Does Global Inequality Matter?" in Global fustice, ed. Thomas W. Pogge, (Oxford: Blackwell, 2001), 106-122; Miller, National Responsibility and Global Fustice. (Oxford: Oxford University Press, 2007), pp. 77-79; Rekha Nath, "Equal Standing in the Global Community," The Monist 94, no. 4 (2011): 593-614; Richard Norman, "The Social Basis of Equality," in Ideals of Equality, ed. Andrew Mason, (Oxford: Blackwell, 1998), 37-51; and O’Neill, "What Should Egalitarians Believe?" Miller is skeptical about social egalitarian concerns arising outside of the state. For the most part, Anderson and Scheffler bracket the issue though Anderson finds it plausible that the ideal might have application between foreigners given global economic ties. See Anderson, "What Is the Point of Equality?" p. $321 \mathrm{ln} 78$ and Scheffler, Equality and Tradition, p. 192n42. The others listed here devote some attention to motivating the case for demands of social equality arising between foreigners.
} 
and 9.5, I argue that such demands could arise with respect to those relations. In section 9.4, I begin to build a case for denying that the basis upon which demands of social equality seem to arise between fellow citizens is exclusively tied to the context of the state. In section 9.5, I continue building that case, focusing on the issue of how we are to determine which measures would be called for to secure relations of equality between foreigners. I explain how satisfying demands of social equality that arise outside of the state might require the adoption of different sorts of measures from those called for within the state. In section 9.6, I address objections to my argument and, in the process, refine my position.

\subsection{Why social equality applies in the state}

In this section, I will discuss both what the demands of social equality consist of and why they arise in the state. Defenders of social equality are rarely explicit about their views regarding the latter issue. I construct an account of why the demands of social equality arise in the state that, if not based directly on ideas they espouse, comports with those ideas. ${ }^{6}$ On some construals of egalitarianism, egalitarian concern applies, in the first instance, to people's relative distributive holdings. Social equality construes egalitarianism differently. ${ }^{7}$ It is an ideal on which people ought to live together on terms of equality. On this ideal the primary object of egalitarian concern is relationships rather than distributions. Samuel Scheffler articulates what it means for the value of equality to apply to relationships, writing that, "the basic reason [equality] matters to us is because we believe that there is something valuable about human relationships that are, in certain crucial respects at least, unstructured by differences of rank, power, or status."8 Based on this construal of the value of equality, defenders of social equality maintain that the aim of egalitarianism is, as Elizabeth Anderson puts it, "to replace social hierarchies with relations of social equality." 9

Social egalitarians do not take issue with all hierarchical relationships. Indeed, as Scheffler observes, hierarchically structured relationships are a pervasive, and perhaps even an inescapable, feature of social life. ${ }^{10}$ What, for defenders of social equality, informs the judgment that certain hierarchical relationships are problematic while others are not? As a starting point in answering this question, consider Thomas Scanlon's claim that "it is an evil for people to be treated as inferior, or made to feel inferior." 11 It seems that the problematic nature of certain hierarchical relationships stems partly from the fact that they make some persons feel inferior to others, causing those parties to endure negative psychological effects.

\footnotetext{
${ }^{6}$ The characterization of social equality I set out in this section is not tied to any particular conception of the ideal. Rather, it is based on what I take to be shared features of the different conceptions advanced by the authors whose views I consider.

7 On how these two construals differ, see Elizabeth Anderson, "Equality," in The Oxford Handbook of Political Philosophy, ed. David Estlund (New York: Oxford University Press, 2012), 40-57, pp. $40-41$ and Scheffler, Equality and Tradition, pp. 191, 199-200, and 228-9. Some of the authors whom I count as defenders of social equality posit a connection between distributive equality and egalitarian relations. For example, see Martin O'Neill in his "What Should Egalitarians Believe?" O'Neill argues that the promotion of these two types of equality will tend to go hand in hand, and he takes the value of realizing egalitarian relations to play a crucial role in explaining the value of reducing distributive inequalities.

${ }^{8}$ Scheffler, Equality and Tradition, p. 225

${ }^{9}$ Anderson, "Equality," p. 40.

10 Scheffler, Equality and Tradition, pp. 225-26.

${ }^{11}$ Scanlon "The Diversity of Objections to Inequality," p. 43.
} 
For instance, take a society that treats gay and lesbian individuals with contempt based on their sexual orientation, denying them formal rights enjoyed by others. This practice may cause gay and lesbian individuals to experience feelings of shame and humiliation and a compromised sense of self-respect.

But such psychological considerations are not the only ones that bear upon whether, for social egalitarians, a hierarchical relation is problematic. Consider Anderson's contention that even if racial segregation in schools did not make black students feel a sense of inferiority to white students, "[i]t would still have been wrong to brand them as inferiors, as the system of racial segregation did." 12 In her view, this assessment would be supported "on account of the principles of contempt or inferiority that [such a practice] expresses, whether or not it has a negative impact on [some persons'] welfare."13 Those statements suggests that on social equality what is objectionable about treating some persons as inferior to others is not reducible to the negative psychological effects that might be experienced by those subject to such treatment.

In addition to such psychological effects, what might explain why certain hierarchical relationships and not others count as problematic? Here it will be helpful to turn to some further cases that defenders of social equality discuss. Social egalitarians hold that a society that denies some but not all of its adult citizens the right to vote thereby fails to treat its members as equals. ${ }^{14}$ Such a practice is regarded as demeaning towards those individuals who are given less of a say in the political process. Social egalitarians also take issue with a government's failure to make public spaces handicapped-accessible. They regard such an omission as objectionable on the grounds that it compromises the ability of disabled individuals to participate as equals in civil society. ${ }^{15}$ And these authors object to a society's allowing significant inequalities in wealth and income between citizens, to the extent that those inequalities give rise to stigmatizing differences in status between individuals who belong to different socioeconomic classes. ${ }^{16}$

Suppose social egalitarians are correct about those cases. That is, suppose that in each case some parties are problematically treated as inferior to others. We might wonder why this is so: why those particular individuals ought not to be treated in the specified ways. To begin with, we can notice that the parties involved in each of those cases are fellow citizens. Indeed, most of the illustrations of unequal relations that social egalitarians regard as problematic involve individuals who are members of the same state. And defenders of social equality take the unequal relations in these cases to be problematic because they embody a failure to treat

\footnotetext{
${ }^{12}$ Anderson, "Anderson replies to Arneson, Christiano, and Sobel," in Brown Electronic Article Review Service, ed. Jamie Dreier and David Estlund (1999).

${ }_{13}^{13}$ Loc. cit. See also O'Neill, "What Should Egalitarians Believe?" p. 130 and Scheffler, Equality and Tradition, p. 228.

14 Anderson, "What Is the Point of Equality?" p. 317; Miller, "Equality and Justice," pp. 30 and 34; Scanlon, "The Diversity of Objections to Inequality," p. 52.

${ }^{15}$ Anderson, "What Is the Point of Equality?" pp. 320, 331, and 334

16 Anderson, "What Is the Point of Equality?" p. 326; Miller, "Equality and Justice," pp. 23-24 and 34-35; Scanlon, "The Diversity of Objections to Inequality," pp. 43, 46, 52; Scheffler, Equality and Tradition, pp. 192-3
} 
individuals as equals in their capacity as citizens. ${ }^{17}$ But why does citizenship matter? It seems obvious that the arbitrary fact that certain individuals happen to be accorded the formal status of citizenship is not of fundamental moral significance. Rather, citizenship is presumably a placeholder for some other facts about membership in the state association that are relevant.

What might be relevant about belonging to a state that would give rise to concerns of social equality? Part of what seems relevant is that the lives of individuals who share a state are bound together in numerous, significant ways such that their standing as citizens will tend to have important implications for nearly all of their relations within the state context. ${ }^{18}$ The state's institutions determine the character of citizens' political, social, and economic interaction - defining their political rights, their social standing, their distributive entitlements, and the design of civil society. And given the dense interconnections that characterize their lives, fellow citizens cannot help but define themselves in relation to one another. Those whose lives are intertwined in these many ways will tend to have shared social and cultural norms that will influence how they regard one another as well as themselves. It is partly because of this sense of a shared identity, which stems from dense interconnectedness within the state, that the terms upon which fellow citizens interact have the potential to convey inferiority to some of those individuals.

Consider how that reasoning can help explain why social egalitarians take issue with the unequal relations between individuals discussed above - an unequal assignment of political rights, a failure to adequately accommodate the handicapped in public spaces, and certain economic inequalities. These are each cases in which some persons fail to enjoy equal standing vis-à-vis their fellow citizens based on their being treated in ways that convey inferiority to them. Whether subjection to a certain form of treatment has the effect of problematically conveying inferiority to some individuals will be crucially informed by a complex interplay of factors: by the nature of interaction between relevant parties, by surrounding attitudes and perceptions, and by shared social and cultural norms. Thus Scanlon suggests that economic inequalities can be troubling if they result in "some people experienc[ing] shame and humiliation because they must live in a way that is far below what most people in the society regard as minimally acceptable." 19 Similarly, Anderson explains how the requirements for participating as an equal in civil society might vary from one society to another. For example, in some countries one may enjoy equal standing only if she is literate in multiple languages whereas in other countries, like the U.S., being literate only in English would not undermine one's standing as an equal. ${ }^{20}$

So, social egalitarian concerns seem to arise in the state because relations of significant interconnectedness between fellow citizens provide a benchmark for defining oneself vis-à-vis others. And based on their mutual identification as members of the same state, the terms of

\footnotetext{
${ }^{17}$ For discussion on the value of treating individuals qua citizens as equals, see Anderson, "What Is the Point of Equality?" pp. 316-320; Miller, "Equality and Justice," pp. 33-4; Scheffler, Equality and Tradition, pp. 191 and 226-8.

18 Pointing to the significant influence state institutions tend to have upon citizens, both Miller and Scheffler suggest that it may be difficult for individuals to relate as equals in general if they do not enjoy equal standing as citizens. See Miller, "Equality and Justice," pp. 33-4 and Scheffler, Equality and Tradition, p. 227.

${ }^{19}$ Scanlon, "The Diversity of Objections to Inequality," p. 52.

${ }^{20}$ Anderson, "What Is the Point of Equality?" p. 319.
} 
their interaction can easily convey inferiority to some. I now wish to consider the matter of when it is that persons have claims to be treated as equals and, correlatively, when persons have obligations to treat others as equals.

Inferiority may be conveyed to individuals in the context of all sorts of relationships. Sometimes an individual who is made to feel inferior has a legitimate complaint, directed at a particular agent, that she ought to be treated as an equal. But not always. Suppose a person feels deeply inferior to his closest friends who, unlike him, excel at sports. Or take a case in which a college student feels a compromised sense of self-worth because, in spite of his hard work, he barely manages to pass his philosophy courses, while some of his classmates easily earn A's. In these two cases, it does not obviously follow from the fact that a person comes to define himself (unfavorably) in relation to certain others, that he has a claim to enjoying equal standing vis-à-vis those others. Thus, we should distinguish cases in which it is merely unfortunate that certain parties relate on unequal terms from cases in which parties to an unequal relationship have claims addressed at certain agents to be treated as equals. ${ }^{21}$

Let us consider why, on social equality, individuals might have legitimate claims to enjoy equal standing vis-à-vis their fellow citizens but do not have parallel claims in the context of certain other relationships (such as those with their friends or classmates). One potentially relevant difference is that individuals' subjection to the institutional terms of the state is, for the most part, unavoidable and nonvoluntary. Indeed, the vast majority of individuals have no say as to whether they are members of the state to which they belong. Yet, as observed above, subjection to the vast array of institutional rules and social norms that is entailed by membership in a given state will tend to pervasively influence how a person fares over the course of her lifetime. ${ }^{22}$ These rules and norms form the backdrop against which virtually all interaction between fellow citizens occurs. So, the interconnections that give rise to the standing individuals have as fellow citizens are the inevitable result of their living together under common institutional arrangements. And because fellow citizens cannot help being enmeshed in the relationships that centrally define this shared sense of standing, it seems

\footnotetext{
21 Drawing a similar distinction, Scanlon explains that he takes cases in which social institutions cause some individuals to feel inferior to others to differ from those in which a person's feelings of inferiority do not have any institutional explanation. He thinks the latter sort of case involves a misfortune and would not legitimately give rise to a moral criticism of society for failing to address it. See Scanlon, "The Diversity of Objections to Inequality," p. 52. Anderson too distinguishes between regarding unequal relations as bad versus condemning them as unjust. She takes social equality to primarily involve such assessments of justice. Judging certain unequal relations as unjust implies, on her view, that some of the involved parties have legitimate complaints about how they have been treated that are directed at specific others. In this respect, the demands of social equality are taken to be agent-relative - objectionable unequal relations will tend to involve a failure on the part of specific agents to meet their obligations to others to promote relations of equality via the design of the terms that characterize the interaction between those parties. See Anderson, "Equality," pp. 44-45; "What Is the Point of Equality?"; "The Fundamental Disagreement between Luck Egalitarians and Relational Egalitarians," Canadian Journal of Philosophy 36 (2012), 1-23, pp. 2-6.

22 Anderson explains that, as she conceptualizes of social equality, the ideal provides a basis for criticizing "durable group inequalities that are systematically sustained by laws, norms, or habits" and not "[i]solated individual inequalities that are detached from systematic social arrangements." See Anderson, "Equality," p. 42. Miller, Scanlon, and Scheffler also focus primarily on cases of unequal relations that are perpetuated by institutional rules and social norms.
} 
that they are each owed, and owe to one another, justification for the character of these relationships as they are defined by society's rules and norms. ${ }^{23}$

These reflections get us closer to what it is about the relationship between fellow citizens that gives rise to demands of social equality. The reasoning I have set out involves two main steps. First, we observe that, due to the dense interconnections between those who share a state, fellow citizens come to define themselves in relation to one another. And because of that shared identity, the terms of their interaction have the potential to convey inferiority to some of them. But that a person defines herself vis-à-vis others does not in itself imply that she has a legitimate claim to enjoy equal standing in relation to relevant others. This brings us to the second step of the reasoning, which points to a further relevant fact: because the dense interconnections between those who share a state are mostly unavoidable, fellow citizens cannot help defining themselves in relation to one another. So, it is because they find themselves significantly and unavoidably interconnected that fellow citizens owe to one another justification for the character of the terms that shape their standing as members of the state. This reasoning suggests an account of the grounds of social equality (that is, of the basis upon which the demand to secure relations of equality arises where it does): demands of social equality arise between individuals whose lives are significantly and unavoidably interconnected by rules or norms that shape their relations with one another.

\subsection{Obstacles for extending social equality outside the state}

I have given an account of why demands of social equality arise in the state, which seems to reflect the commitments of those who take them to. In the next section, I will argue that if the case for social egalitarian demands arising in the state based on that account is sound, then these demands can also arise between individuals who do not share a state. The latter claim, that such demands can arise between foreigners, might seem implausible. ${ }^{24}$ In this section, I will explain why. That is, I will articulate reasons that might be given for the view I reject, that the call to structure relations on egalitarian terms can arise only in the context of the state. ${ }^{25}$

The relationship between fellow citizens differs markedly from the relationship between foreigners. To begin with, there is no global society in which all individuals

\footnotetext{
${ }^{23}$ In the context of the state, Anderson takes citizens to have obligations to one another to justify the character of the terms that they jointly uphold and impose on one another. See her "What Is the Point of Equality?" p. 313 , 314,332 , and 336 .

24 Above (in footnote 1) I noted that my use of the term "foreigners" includes two different groups: first, individuals who reside in the same state but are not fellow citizens, and, second, individuals who are not fellow citizens and reside in different states. One might think that demands of social equality arise between those in the first group but not between those in the second. In what follows, however, I argue that demands of social equality can arise in both cases. So, my argument about the scope of this ideal takes as its target those who maintain that social egalitarian demands cannot arise between foreigners at all as well as those who think that such demands can arise between foreigners but only when they reside in the same state as one another.

25 Some of the reasons for skepticism about social egalitarian demands arising between foreigners that I consider here are also discussed by Miller, National Responsibility and Global Fustice, pp. 77-79 and Satz, "What is the Point of International Equality? Comments of Darrel Moellendorf's Cosmopolitan Fustice," International Fournal of Politics and Ethics 3, no. 2 (2003): 224-239, at pp. 229-31 and 234-5. See also Freeman, Justice and the Social Contract (New York: Oxford University Press, 2007), pp. 267-73 and 294 on the distinctive nature of the relationship between fellow citizens.
} 
worldwide are granted recognition as members. Moreover, there is no global association within the context of which individuals from different states partake in a multitude of shared political, social, and economic practices that significantly shape their day-to-day lives. Interaction between foreigners has a more fragmented character than interaction between fellow citizens. For example, it seems that a Bangladeshi sweatshop worker may have no connections with foreigners beyond the fact that she stitches garments that will be sold by companies based in countries she will never visit and worn by people she will never meet. Likewise, the lives of seasonal migrant workers, fishermen affected by trade arrangements, and manufacturers and consumers of generically produced drugs may not be densely interconnected with those of foreigners. And while the rules of a state will tend to influence most aspects of the lives of its members, the lives of some individuals worldwide may remain relatively unaffected by transnational rules and norms despite increasing globalization. Simply put, there seems to be no global equivalent of the state.

Furthermore, although many foreigners interact and influence one another's fates in numerous ways, they might not see themselves as having much else in common. More likely, they will tend to feel a greater sense of belonging with members of their own respective political societies, each with its distinctive cultural traditions, norms, and practices. Foreigners often speak different languages, and social interaction between them is typically minimal when compared to that between fellow citizens. For these reasons, it seems that foreigners will not tend to feel a sense of mutual identification or define themselves vis-à-vis one another. And if the lives of foreigners are not significantly intertwined so as to give rise to a common identity, then there would not seem to be a reference point for these individuals to make claims to be treated as equals in relation to one another. Consequently, it is not clear that the terms of their interaction even have the potential to objectionably treat some of them as inferior.

In addition, even if certain unequal relations between foreigners appear to problematically treat some of them as inferior, it is not at all obvious who, or what, would be the addressee of such complaints. In the context of the state, fellow citizens are taken to have obligations to one another to ensure that institutional rules and norms do not avoidably perpetuate unequal relations between them. Consider a state in which the institution of marriage is predicated on inegalitarian terms that favor men over women. Social equality does not, in the first instance, imply that married individuals in this state ought to treat their spouses differently so as to reduce gender-based disparities. Rather, social equality in this case primarily calls for altering the institution of marriage so as to avoid systematically producing patterns of gender-based discrimination. Analogous reasoning applies to other instances of unequal relations in the state: the claims fellow citizens have to be treated as equals are to be satisfied via the design of rules, norms, and social practices that shape their relations. However, as was noted above, individuals worldwide do not belong to anything like a unified global society - that is, there is no single set of background rules that define the terms upon which they interact. And so, even in a case in which problematically inegalitarian relations might arise between foreigners, there seems to be a puzzle concerning to whom claims foreigners might make to be treated as equals would be addressed.

There is yet another reason to be skeptical of the prospect of demands of social equality applying outside of the state context. One cannot realistically avoid standing in relations of interdependence with one's fellow citizens. But relations of interdependence 
between foreigners might not seem similarly unavoidable. If we consider the arrangements characterizing cross-border relations that I surveyed at the outset of this essay, it might seem that interaction between foreigners is often a matter of choice. For instance, it seems that individuals from different states have the option of avoiding participation in transnational networks of trade, labor, and production. Voluntary arrangements are generally thought to give rise to different standards of justification than non-voluntary ones. Even if certain terms of interaction favor some individuals subject to them over others, those terms may be justified if they are freely consented to by those parties. Thus, the idea that demands of social equality can arise between foreigners appears to face significant challenges.

\subsection{The case for extending social equality outside the state}

In this section and the next, I will argue that, despite the challenges described in the previous section, demands of social equality can arise between foreigners if they can arise between fellow citizens. Let us begin by recalling the reason demands of social equality appear to arise within the state. Because the state pervasively affects the lives of its members, it seems that fellow citizens will tend to define themselves in relation to each other. And in light of citizens thereby having a sense of standing vis-à-vis one another, there is a potential for their interaction to convey inferiority to some. Further relevant is the observation that individuals tend to have no choice concerning their subjection to the state's terms. Fellow citizens therefore find themselves unavoidably linked to one another. This reasoning suggests that defenders of social equality support a principle along the following lines: individuals whose lives are unavoidably bound together have claims on one another to ensure that the terms regulating their interaction do not treat some of them as inferiors. The flip side of this principle states that individuals so positioned are mutually obligated to structure their interaction on terms that respect each person's standing as an equal.

I will argue that, on reflection, that reasoning leads to the conclusion that demands of social equality are not restricted in their application to the context of the state. Consider a case that builds on one discussed by Michael Blake. ${ }^{26}$ Borduria and Syldavia are societies that reside on opposite sides of a mountain, and members of each have long been unaware of the other's existence. The Bordurians enjoy a much higher standard of living than the Syldavians, which is partly due to the comparative abundance of valuable natural resources in the Bordurian territory. One day, a few Syldavians traverse the mountain and find themselves in Borduria. These Syldavians, the first to make their way into Borduria, marvel at how much better things are on this side of the mountain. Wandering into a vast orchard, they stake a claim to a few small plots, which look rather neglected. After the Syldavians have been tending to their newly acquired land for a few months, some Bordurians inform them that they are trespassing and that if they do not leave immediately local authorities will be called.

I will now argue that social egalitarian demands arise between the Bordurians and Syldavians. The first step of this argument will involve showing how problematically

\footnotetext{
${ }^{26}$ Michael Blake, "Distributive justice, State Coercion, and Autonomy," Philosophy \& Public Affairs 30, no. 3 (2002): 257-296, at pp. 289-94. Blake bases his case on one devised by James Buchanan in "A Two-country Parable," in Fustice in Immigration, ed. Warren F. Schwartz, (Cambridge: Cambridge University Press, 1995), 6366.
} 
inegalitarian relationships can emerge between the Bordurians and Syldavians even though they are not fellow citizens. Suppose that after the initial Syldavian explorers make their way into Borduria, the Bordurians adopt strict border control policies that prevent Syldavians from entering their society unless they are granted visas. Over the following decades, the Bordurians and Syldavians forge various economic ties. Sweatshop factories are established in Syldavia. These factories draw on the cheap and abundant local labor force of Syldavia to manufacture goods produced by Bordurian companies for Bordurian consumers. Further, some Syldavians take up the lowest paying jobs in Borduria, requiring them to perform menial and sometimes dangerous tasks. These immigrants reside in slums populated only by other Syldavians. Due to language barriers and their different customs, the Syldavian immigrants are not integrated into the broader civil society of Borduria. They feel a sense of isolation. Although they reside and work in Borduria for many years, they are offered no path to citizenship and their children are not admitted to Bordurian public schools. The Bordurians look down on the Syldavian immigrants and prefer to minimize interaction with them. They make no effort to work towards greater social inclusion of these foreigners.

Suppose that the various cross-society economic practices, though mutually beneficial, disproportionately serve the Bordurians' interests. Owing to those practices, the average Bordurian consumer now has access to a wider range of cheap manufactured goods than before, and the standard of living is improving across the board for Bordurian citizens. By contrast, Syldavian citizens are only slightly materially better off as a result of the cross-society arrangements. As the lives of the Bordurians and Syldavians become more integrated over the years, individuals from either society come to cultivate a stronger sense of a shared identity. Prior to establishing these arrangements, the Syldavians accepted their way of life, knowing no other possibility. Now they strive for what the Bordurians have. But opportunities for social and economic advancement are lacking. As their interdependence grows over generations, the increasing material disparity between members of either society results in the Syldavians feeling as though they belong to a virtually inescapable underclass.

The Bordurian-Syldavian case illustrates how unequal relations can convey inferiority between parties who are not fellow citizens. In this case, the lives of the Bordurians and Syldavians eventually become sufficiently interconnected such that the unequal terms shaping their interaction have the effect of treating some of them as inferiors. The inegalitarian nature of the relations between the Bordurians and Syldavians may strike us as unfortunate. But is it furthermore the case that the Syldavians have a claim to be treated as equals vis-à-vis the Bordurians? They do. To see why this is so, let us recall the initial encounter between members of these two societies - when the Bordurians arrive at the orchard and find that some foreigners, the Syldavians, have been occupying some of their land. From that moment onward, we can say that those Bordurian and Syldavian individuals are positioned to make competing claims to the land at issue. What that means is that these individuals are able to make claims to the use and ownership of the same material holdings: claims that cannot be mutually satisfied. And in the face of competing claims, there is the potential for conflict. A conflict might arise if, for example, a Syldavian and a Bordurian each make a claim to exclusive control over the same plot of land.

The competing claims that Bordurians and Syldavians are positioned to make are not limited to a potential dispute over plots of this orchard. More generally, given the proximity of 
the two societies and their awareness of one another's existence, members of each society are now positioned to make competing claims to the use and ownership of all manner of material holdings. Thus, we can imagine some poorer Syldavians wishing to occupy a wealthy Bordurian family's vacant summer home, or to fill their thermoses with drinking water from babbling brooks in Bordurian forests, or to help themselves to berries growing in a Bordurian's garden. That these foreigners now find themselves positioned to make such competing claims is significant. Whenever parties are positioned to make such competing claims, addressing how those claims are to be resolved is, in a sense, unavoidable for them. It might seem otherwise. After all, such parties could elect to leave each other alone, by refraining from making claims that would be in conflict with the claims of others or by withdrawing any claims they have made that turn out to have this consequence. So, for example, following their initial encounter with the Bordurians, suppose that the Syldavians choose to abandon the plots on the orchard and return to their home country. However, retreating in this way is not neutral: it reflects one way that the competing claims can be resolved. The Syldavians' decision to retreat settles the conflict in the Bordurians' favor. Effectively, then, retreating is a way of addressing competing claims. So, once parties are positioned to make competing claims, the question of how those potential claims ought to be adjudicated arises.

Let me clarify the reasoning here. I am not claiming that parties who are positioned to make competing claims cannot, as a practical matter, avoid the adoption of formal, publicly known, and settled rules or norms that would provide a basis for resolving potential conflicts. Rather, I am claiming that, in the face of competing claims, at any given moment these claims will be addressed in some way or another - whether by actions or omissions on the part of some or all of the involved parties. I take this claim to apply to ongoing disputes, in the course of which different parties might, at different points in time, exercise de facto control over the material holdings at issue; and also to cases in which there is little risk of conflict arising and consequently little practical need for the adoption of terms that would serve to adjudicate between competing claims. My basic point is that across these different scenarios, so long as there are such competing claims, a subject matter for moral assessment necessarily obtains. That is, how such competing claims are addressed stands in need of justification to the parties positioned to make them.

We now can see why it is implausible to regard the unequal relations that eventually emerge between the Bordurians and Syldavians as merely unfortunate. It seems clear that, as I described the case, the terms that serve to resolve the competing claims Bordurians and Syldavians are positioned to make fail to treat these individuals as equals. Those terms consist of the various rules and norms that define and uphold the distributive entitlements the Bordurians and Syldavians respectively enjoy. Consider the terms from the Syldavians' perspective. Syldavians are prevented from entering Borduria except under the conditions specified by Bordurian immigration policies. Furthermore, the claims Bordurian citizens have to all the material holdings within their borders - ranging from their use of public land to their ownership of private property - are enforced against the Syldavians. Under this arrangement, significant material inequalities between the Bordurians and Syldavians persist, and these material inequalities translate into inegalitarian relations between these foreigners. The perpetuation of such inegalitarian relations is not inevitable. A different design of the terms regulating cross-society interaction could enable more egalitarian relations. For instance, more 
egalitarian relations might emerge under an arrangement that produces less cross-society material inequality. Alternatively, perhaps through the adoption of policies promoting greater social inclusion of Syldavian immigrants in Bordurian society, the translation of significant material inequalities into inegalitarian relations could be prevented.

The Borduria-Syldavia case illustrates how the reasons advanced for taking demands of social equality to arise between fellow citizens provide a basis for taking such demands to arise between foreigners. Fellow citizens are seen as having obligations to each other to ensure that the shared rules and collective practices they uphold do not produce objectionably unequal relations. This is because significant interconnectedness between fellow citizens is virtually unavoidable. Analogously, the lives of the Bordurians and Syldavians too are unavoidably linked. Once positioned to make competing claims, the Bordurians and Syldavians cannot avoid addressing how those claims are resolved in some way or another. At the initial point at which these foreigners find their lives unavoidably bound together, significant interconnectedness is not present. However, over time, interconnectedness that gives rise to a sense of shared standing between the Bordurians and Syldavians develops, and this in turn makes it possible for some of them to be problematically treated as inferiors. Thus it seems that the Syldavians have a claim for their relationships with the Bordurians to be structured on terms of equality. So, the demands of social equality can have a wider scope than one might have thought.

\subsection{What social equality outside the state requires}

Now I turn to the issue of what sorts of substantive measures might be called for where demands of social equality arise between foreigners. This issue seems to be an important one given the considerable differences in interaction between foreigners as compared to interaction between fellow citizens. As I have noted, the lives of fellow citizens tend to be marked by significant political, social, and economic interconnectedness, while interaction between foreigners tends to have a comparatively fragmented character. Consequently, individuals tend to feel a stronger sense of mutual identification with their fellow citizens than they do with foreigners. Moreover, in the state context, we have clearer intuitions about certain practices, such as racial segregation in public schools and the formal disenfranchisement of some classes of citizens, being incompatible with treating all fellow citizens as equals. But with respect to relationships between foreigners, it seems less clear which practices threaten to undermine their ability to live together as equals. In this section, I will address these issues.

What is called for to secure relations of equality varies from case to case. As the lives of foreigners become more interconnected, the prospects for problematic inegalitarian relations emerging between them increase. Accordingly, what is required to maintain equal standing may be substantial. For instance, consider the case of the Bordurians and Syldavians years after their initial encounter, when numerous cross-border ties have been forged. To avoid the stigmatization of long-term Syldavian residents, Bordurians may be required to grant those individuals the opportunity for citizenship and its associated privileges. And the persistent lack 
of social and economic mobility endured by the Syldavians as the Bordurians grow ever wealthier may call for measures that expand the Syldavians' opportunities for advancement. ${ }^{27}$

In other cases, the demands of social equality may be relatively modest. For example, suppose that for many years following their initial encounter the Bordurians and Syldavians have almost no contact with one another. In this scenario the two peoples simply do not stand in the sorts of hierarchical relationships that would seem to conflict with the demands of social equality. But that is not to say that social egalitarian demands do not arise. On the contrary, they do. To see why, recall the point of first contact between the two societies. At that moment, the persons involved are positioned to make competing claims. And as we have seen, such competing claims must be addressed in some manner. How they are addressed ought to be justified to each of the parties so positioned. Any way in which those competing claims are addressed that leads to problematic inegalitarian relations would not be justified. So, in that sense, demands of social equality are in play from the outset. That is, from the start, each of these individuals has a claim to that which is needed to secure his or her equal standing in relation to the others. What that implies - precisely what is needed to secure equal standingdepends on the nature of interaction between the relevant parties. But on social equality, each person subject to terms that unavoidably shape her interaction with others is owed treatment as an equal, even when that interaction is minimal.

We are now in a position to address a different concern raised above, in section 9.3. It may seem that a great deal of interaction between foreigners, unlike between fellow citizens, is optional. For example, it might seem that the Bordurians and Syldavians need not interact at all. Certainly it looks as though the Bordurians are under no obligation to outsource labor to Syldavia or to hire foreigners as migrant workers. And if they need not interact at all, then it seems that they would not be obligated to relate on equal terms if they choose to interact in these ways. ${ }^{28}$ And if this is so, the reasoning goes, then it is a mistake to conclude that their interactions, extensive though they may eventually become, ought to be predicated on egalitarian terms. In other words, although demands of social equality apply between individuals who cannot avoid partaking in a densely interconnected political, social, and economic life, such demands do not arise between those for whom partaking is optional.

But that argument is unconvincing for two reasons. First, demands of social equality arise even in cases in which foreigners choose to avoid interacting in particular ways - for instance, by opting not to forge transnational labor ties or by instituting closed-border immigration policies. Foreigners who are positioned to make competing claims cannot avoid regulating their interaction in some way. Therefore, how they do so stands in need of justification. The terms regulating these individuals' interaction should not undermine their ability to enjoy equal standing in relation to each other. As in the minimal-interaction Bordurian-Syldavian case discussed two paragraphs back, the substantive measures called for

\footnotetext{
27 I agree with other social egalitarians that the issue of working out what is required to realize relations of equality in particular cases must be sensitive to the views of the participants of the given relationships. Thus, from an impartial, removed perspective, only so much can be done in identifying which specific practices are in tension with egalitarian relations and what remedies are called for in those cases. See Anderson, "What Is the Point of Equality?" and "Equality," p. 55; Scheffler, Equality and Tradition, p. 226.

${ }^{28}$ For appeal to this sort of reasoning, see Blake, "Distributive Justice, State Coercion, and Autonomy," p. 292.
} 
to maintain equal relations between foreigners may be extremely modest. But modest demands are demands nonetheless.

Second, it does not follow from the fact that certain parties can (as a matter of feasibility) avoid relations of significant interconnectedness that such avoidance would be morally permissible. It is not hard to imagine cases in which a failure to interact in certain ways would itself objectionably convey inferiority. Suppose that after many decades of significant cross-border economic interaction the Bordurians decide one day to sever all ties with the Syldavians, suddenly terminating contracts with all sweatshops and deporting all Syldavian migrant workers. They do this on the grounds that they regard the Syldavians as having a backwards culture that is inferior to their own, and they do nothing to hide that ugly rationale. This course of action seems to run afoul of the demands of social equality no less than in other cases we have considered. Analogously, suppose that the American government were to respond to complaints about the inferior treatment of black citizens implied by racial segregation of schools by dismantling the public school system altogether, rather than by aiming for integration of those schools. As that case illustrates, disengaging from those treated as inferior by reducing interaction with them can itself problematically convey inferiority. So, all that the considerations concerning choice and the possibility of disengagement show is what I have already granted: social egalitarian demands between foreigners may be satisfied, in some instances, by less robust measures than those that are generally required in the state context.

\subsection{Objections and replies}

I have argued that social egalitarian demands can arise between individuals who do not share a state if such demands arise between individuals who do. In this section, I consider some objections. To begin with, one might object that my account of grounds is based on an implausible claim about when individuals are owed justification: that a demand for justification arises between individuals solely on the basis of their being positioned to make competing claims over material resources. ${ }^{29}$ To see why that claim might seem implausible, consider an example. Suppose that my neighbor admires my stylish bicycle, and she would very much like to take it from me. It is one of several in my vintage collection. She thinks it unfair that I have so many fine bicycles while she cannot afford to buy even one. Since she could easily steal this bicycle from me, she is positioned to make a claim to it - a claim that competes with my mine. My account seems to imply in this case that my neighbor is owed justification for how this dispute is resolved. And so, perhaps in light of the value of reducing inequality, a justified resolution to these competing claims would deem my neighbor as the rightful owner of this bicycle. But that seems absurd. This suggests that justification for how distributive entitlements are determined does not arise simply because some people happen to be positioned to make competing claims to some goods. Instead, what seems to matter is whether people have legitimate standing to make competing claims in the first place.

I agree that if my account of grounds (combined with claims about the value of reducing the inequality in this case, which can be granted for the sake of argument) leads to the conclusion that my neighbor is the rightful owner of my bicycle, then the account should

\footnotetext{
${ }^{29}$ I am grateful to the editors of this volume for raising this objection.
} 
probably be rejected. Fortunately, my account does not have that consequence. My account does imply that my neighbor is owed justification for how the dispute over the bicycle is settled. But that justification does not in the first instance concern our competing claims over the bicycle taken in isolation from the design of the background institutions of our society. Rather, the justification directly concerns the design of those background institutions that determine individuals' distributive entitlements. Consequently, the resolution of this dispute will count as justified to my neighbor if the property rights system upheld by our society is just. If our society is just, and its rules recognize me as the rightful owner of the bicycle, then my neighbor may not legitimately take it from me.

A different objection is that my argument focuses too much on individuals and fails to give sufficient attention to the rights of political societies. For example, much of my discussion centers on the competing claims that Syldavian citizens are positioned to make to the distributive holdings claimed by Bordurian citizens. In focusing on how the property rights of Bordurian citizens impose claims on Syldavian citizens, the objection runs, I have ignored a more fundamental right that is at play in this case: the territorial right of the Bordurian society at large. Unlike property rights of individuals, which are a matter of the ownership and use of material holdings, territorial rights claimed by states have a broader scope. ${ }^{30}$ Territorial rights are generally taken to consist of three main components that apply within specified boundaries: a jurisdictional right to impose laws, a right to use and control territory and natural resources, and a right to exclude outsiders from entry. ${ }^{31}$

Shifting the focus from individuals' property rights to states' territorial rights potentially introduces morally relevant considerations that have thus far been absent from my discussion. Some authors argue that the exercise of territorial rights enables states to provide morally valuable goods for their members. Different accounts of the morally valuable goods that states provide their members have been defended-including, for instance, selfdetermination, the protection of individual autonomy and basic liberties, and the realization of distributive justice. ${ }^{32}$ The defense of territorial rights grounded in these sorts of considerations takes the following general form. Call the given morally valuable good or set of goods that a state secures, or is positioned to secure, $x$. A state's ability to realize $x$ for its members depends on its ability to exercise a territorial right, which entails the imposition of some claims on outsiders. Thus, to the extent that a state does, or is positioned to, secure $x$ for members, it is justified in exercising a territorial right against outsiders. And if a state is justified in exercising a territorial right against outsiders, then it seems to follow that the state does not owe justification to those outsiders for the character of cross-society relations that may emerge based on its legitimate exercise of that right.

\footnotetext{
30 See, for instance, Freeman, Fustice and the Social Contract, p. 286 and pp. 307-308.

31 This characterization of territorial rights is based on David Miller's in "Territorial Rights: Concept and Justification," Political Studies 60, no. 2 (2012): 252-268, at pp. 252-253.

32 See the following defenses of territorial rights: Miller, National Responsibility and Global fustice; Cara Nine, Global Fustice and Territory (Oxford: Oxford University Press, 2012); A.J. Simmons, "On the Territorial Rights of States," Philosophical Issues 11 (2001): 300-326; and Anna Stilz, "Why Do States Have Territorial Rights?" International Theory 1, no. 2 (2009): 185-213. Some authors take a state's territorial right to derive from the rights of individual members of that state, while others take it to derive from the rights of collective agents, such as nations.
} 
But this objection is no more convincing than the previous one. The first point to note about this sort of defense is that the territorial rights of states that it delivers are prima facie rights. And this is just what we would expect. For defenders of territorial rights, that a state secures $x$ for its members does not imply that it enjoys an unconditional territorial right - for instance, permitting a state to claim as much territory as it pleases regardless of the implications this would have for outsiders. ${ }^{33}$ Rather, how far-reaching a state's territorial right is must be sensitive to concerns about how those against whom it is enforced would be affected. So, taking the territorial rights of states rather than the property rights of individuals as a starting point does not undermine my claim that foreigners are owed a justification for the nature of the claims that would thereby be imposed on them. Moreover, it is instructive to note that from the perspective of parties like the Syldavians, it will likely make little difference whether we focus on the claims that would be imposed on them by the Bordurian state's territorial right or by Bordurian citizens' property rights. In either the case the practical upshot may be the same.

Since in shifting focus to territorial rights a demand for justification to foreigners would still arise, what we must assess is the basis for concluding that considerations of social equality would not be a part of that justification. I see no good reason for drawing that conclusion. If one believes otherwise, then perhaps one is reasoning as follows. Making a state's exercise of its territorial right conditional upon its satisfying cross-society demands of social equality could undermine that state's capacity to secure $x$ for its members. For instance, suppose that on social equality the Bordurians must adopt measures enabling much greater social integration of Syldavian immigrants in their society. And suppose further that the adoption of such measures could place a significant strain on the Bordurians' capacity to preserve culturally distinctive traditions that are important to their community. In this sort of case, it appears that satisfying social egalitarian demands could infringe upon the self-determination of the Bordurian people. ${ }^{34}$

My reply to this move is two-fold. First, this concern about social egalitarian demands applying between foreigners is a conditional one. It applies only in scenarios in which striving for egalitarian relations between foreigners would actually conflict with a state's ability to secure $x$. But, conceivably, there are cases in which the pursuit of more egalitarian relations between foreigners would not clash with those other values. For instance, it seems possible that the social inclusion of Syldavians could be promoted without infringing upon the Bordurians' exercise of self-determination. For the objection to threaten my argument, it would have to be shown that demands of social equality necessarily conflict with the realization of $x$. And that seems doubtful.

Second, even in cases in which the pursuit of relations of equality between foreigners would come into conflict with the realization of $x$, it is not clear that this would provide a basis for concluding that the demands of social equality do not arise in that context. I do not suggest that the call for egalitarian relations categorically trumps other moral considerations. I take

\footnotetext{
33 See, for instance, Miller, National Responsibility and Global fustice, p. 221.

${ }^{34}$ Christopher Heath Wellman defends this sort of line in his "Immigration and Freedom of Association," Ethics 119, no. 1 (2008): 109-141. Based on the value of self-determination, Wellman argues that legitimate states have a right to close their borders and thereby to exclude foreigners with whom their members do not wish to interact.
} 
the value of realizing relations of equality to play a constitutive role, alongside other values, in determining how interaction across (and within) societies ought to be regulated. ${ }^{35}$ In this regard, my defense of social egalitarian demands arising between foreigners is modest. Accordingly, in cases of conflict, I think we must consider what is at stake in promoting one value at the expense of another. It seems that social egalitarian considerations should count for something. Plausibly, if terms that individuals are unavoidably subject to perpetuate deeply inegalitarian relationships between those individuals, then those terms would be unjustified in that respect to those treated as inferior, and perhaps also to the others. ${ }^{36}$ So, the onus seems to fall upon my opponent to explain why considerations of social equality should be given no weight at all in justifying such terms.

Consider a different challenge to the claim that demands of social equality can arise between foreigners. One might hold that these demands arise in the state, but not beyond it, based on the distinctive nature of cooperation in the state. ${ }^{37}$ This challenge begins with the observation that cooperation between fellow citizens makes possible the production of significant social and economic benefits within the bounds of a state. Then, it is argued, because each member of the state partakes in such cooperative relations, she ought to be able to participate as an equal alongside her fellow citizens in sharing in the gains thereof. Thus, demands of social equality might be taken to arise in virtue of cooperative relations of this kind, rather than relations of interconnectedness more generally. The next step of this challenge points to the observation that foreigners do not appear to cooperate in an analogous way: that is, there seems to be no cross-society cooperation that produces social and economic gains on a par with those produced within states. Consequently, it appears that there is no set of social and economic benefits with respect to which foreigners would have claims to being treated as equals. Even if certain inegalitarian relations that arise between foreigners are unfortunate, it seems that requiring members of better-off societies to remedy the unequal character of those relations would problematically infringe on their entitlements to the gains of domestic cooperation.

One response to this objection is to reject the premise that the social and economic gains enjoyed by members of one society do not tend to rely on the cooperation of foreigners. As I argued in section 9.4, once individuals from Borduria and Syldavian are positioned to make competing claims, it seems that the Bordurians' ongoing, secure enjoyment of their property as defined by the Bordurian government depends in part on Syldavians' compliance with that property rights scheme. Because of this it seems that the Bordurians owe the Syldavians justification for the terms of that arrangement that are imposed upon them. Thus, even if the cooperative efforts of the Bordurians play an important role in producing and sustaining the social and economic benefits that they enjoy, the cooperation of the Syldavians

\footnotetext{
${ }^{35}$ Defenders of social equality do not take the value of egalitarian relations to be exhaustive of that which individuals owe to one another. See, for instance, Anderson, "Expanding the Egalitarian Toolbox: Equality and Bureaucracy," Aristotelian Society Supplementary Volume 82, no. 1 (2008): 139-160, p. 144n4.

${ }^{36}$ For discussion of how unequal relations may be a bad thing for those who are treated more favorably or a bad thing in itself, see Anderson, "Equality," pp. 44-5 and 50-51; O’Neill, "What Should Egalitarians Believe?" p. 130; Scheffler, Equality and Tradition, p. 227-8.

${ }^{37}$ For defense of this sort of reasoning, see John Rawls, The Law of Peoples (Cambridge M.A: Harvard University Press, 1999), pp. 113-119 and Freeman, Fustice and the Social Contract, pp. 305-307.
} 
seems to be an additional relevant factor that contributes to the Bordurians' enjoyment of the same.

Even so, the objector may respond, it still seems that less is owed to foreigners than to one's fellow citizens since cross-society cooperation is much less robust than domestic cooperation. This is because the background institutions of the state profoundly and pervasively affect citizens' lives, while cross-society rules and norms do not. Samuel Freeman offers a characteristic articulation of this view, pointing to some of the significant functions carried out distinctively by states. He writes, "[i]t is not just fiscal policies, taxation, public goods, and welfare policies...more basically, it is political decisions about the multiplicity of property rules and economic norms and institutions that make possible these policies, and economic and social cooperation as well." ${ }^{38}$ He continues, noting that "global norms pale in comparison." 39 Thus, it follows, on this line, that one owes significantly less to foreigners than one owes to one's fellow citizens. Indeed, those who point to the disanalogous nature of crosssociety cooperation generally argue that foreigners are owed consideration only for their absolute levels of well-being and nothing more. ${ }^{40}$

The reasoning here seems to be that the comparatively laissez-faire nature of crosssociety cooperation implies that any obligations that arise between foreigners would call for much less than do those that arise between fellow citizens. First, we should notice that this conclusion does not threaten my view. I claim that obligations of social equality can arise between foreigners if such obligations can arise between fellow citizens. I do not claim that the content of the obligations that might arise in both cases would be the same. Second, the reasoning is suspicious. Consider how analogous reasoning could be invoked to explain why less would be owed to society's worse-off citizens in the libertarian's favored "nightwatchman state" - that is, a state that carries out the sole function of enforcing a libertarian property rights scheme - than in a social welfare state. In the nightwatchman state, imagine that a social policy is proposed that would raise income taxes for wealthy citizens for the purpose of bringing about greater social mobility for society's poorest members. A rich citizen might protest this policy by pointing to the apparently minimal level of cooperation between her and the poor: "I earned my wealth through my own hard work. All that my poor fellow citizens did was comply with the state's property rights laws. In return, it seems absurd that they should have a claim to a hefty proportion of my earnings to enable their participation as equals in society. Instead, all they are owed by me is what they already enjoy: that I, in turn, respect their property rights."

I will not rehearse here familiar considerations advanced against such libertarian reasoning when appealed to in the state context. For present purposes, it is enough to note

\footnotetext{
${ }^{38}$ Freeman, Fustice and the Social Contract, p. 306.

${ }^{39}$ Loc. cit.

${ }^{40}$ Variants of this claim are defended in the literature. Blake, Sangiovanni, and Nagel maintain that badly-off individuals have claims on foreigners only to that which they need to avoid threats to the fulfillment of their basic needs. See Blake, "Distributive justice, State Coercion, and Autonomy"; Andrea Sangiovanni, "Global Justice, Reciprocity, and the State," Philosophy E् Public Affairs 35, no. 1 (2007): 3-29; and Thomas Nagel, "The Problem of Global Justice," Philosophy \& Public Affairs 36, no. 2 (2008): 113-147. See also Rawls's argument in The Law of Peoples that worse-off states are owed assistance only up to the level at which they are able to establish minimally decent social institutions.
} 
that those who would reject demands of social equality arising between foreigners based on this reasoning reject the application of such reasoning when applied within the state. Thus, if they wish to apply parallel reasoning in cross-society cases, they should explain why it does not fall prey to parallel objections.

It may be argued that demands of social equality do not arise outside of the state because the application of those demands to relations between foreigners would be rejected not only by members of better-off states but also by members of worse-off states. Perhaps this claim would be defended on the grounds that all individuals would favor the greater scope for political autonomy afforded to states by a cross-border arrangement that does not contain a commitment to social equality. But if we give serious consideration to the perspective of those, like the Syldavians, whose interaction with foreigners would be predicated potentially on deeply unequal terms that treat them as inferiors, the plausibility of that claim seems questionable. Granting the, perhaps dubious, claim that those in worse-off states would actually enjoy the posited benefit of a laissez-faire cross-society system, would that benefit be worth the cost of such unequal relationships for them? Again, why the value of egalitarian relations ought to be given no weight against other potentially relevant considerations in the cross-society context would need to be explained.

\subsection{Conclusion}

Social egalitarians have sought to articulate the value of individuals living together on terms of equality. The ideal of social equality thus provides a basis for explaining what is wrong with a wide range of hierarchical practices that treat some people as inferior to others. Generally, this ideal is discussed as it applies in the context of the state to the relations between fellow citizens. In this essay, I have argued that the considerations that seem to explain why social egalitarians take demands of social equality to arise between fellow citizens provide a basis for those demands also arising between individuals who do not share a state. ${ }^{41}$

The practical implications of that conclusion may be far from trivial, as reflection on the real-world inegalitarian practices I described at the outset makes plain. But without further assumptions, my argument does not necessarily imply that such practices are incompatible with the demands of social equality. Indeed, although I do think that social equality offers a plausible explanation of the value of equality, in this essay, I have neither sought to defend social equality nor have I endorsed any particular conception of it. Moreover, whether there is in fact such an incompatibility depends on empirical details about the relevant practices and

\footnotetext{
41 Others who defend the view that social egalitarian concerns might arise outside of the state do not, for the most part, address the issue of grounds that I have explored in this essay. See, for instance, Beitz, "Does Global Inequality Matter?" O’Neill, "What Should Egalitarians Believe?" and my "Equal Standing in the Global Community." For these authors, the existence of unequal relations between foreigners may reflect a morally bad state of affairs. But they do not take up the further question of whether foreigners who are party to unequal relations have claims to be treated as equals that are addressed to particular agents. Norman is a noteworthy exception. In "The Social Basis of Equality," he sketches a view that is similar to the one that I have set out here. Norman argues that demands of social equality have application beyond state borders based on facts about global cooperation, and he takes the unequal nature of global cooperative relations to reflect wrongdoing in which at least some of the participants of those relationships are implicated. He does not, however, offer a detailed account of the grounds of the ideal as I have sought to do here.
} 
their participants, matters about which my argument is silent. So, my argument does not provide a basis for concluding which, if any, relations between foreigners might violate the demands of social equality. The most my argument shows is that a violation of social egalitarian demands between foreigners is not ruled out on conceptual grounds.

In addition to this implication about the scope of social equality, the arguments I have presented here also suggest a positive account of the grounds of the ideal. On this account, demands of social equality arise between individuals who cannot help their lives being intertwined in ways that have the potential to generate objectionably inegalitarian relations between them. Individuals so situated have obligations to one another to justify the terms defining their interaction by securing equal standing for all those subject to them. Precisely how the grounds of social equality should be construed is a large question, and the account I have sketched requires further explication and defense. So, in this respect too, I do not take my arguments to support definite conclusions that would provide a basis for criticizing specific real-world inegalitarian relations. And applying the insights of social equality to relationships outside of the state faces distinctive obstacles, in particular pertaining to the reconciliation of the demands of social equality with other morally relevant considerations. Nevertheless, I have put forward a framework that makes room for addressing such concerns. ${ }^{42}$

\section{References}

Anderson, Elizabeth. "What Is the Point of Equality?” Ethics 109 (1999), 287-333.

—_. "Anderson replies to Arneson, Christiano, and Sobel," Brown Electronic Article Review Service, ed. Jamie Dreier and David Estlund (1999), available at: http://www.brown.edu/Departments/Philosophy/bears/9912ande.html

- "Expanding the Egalitarian Toolbox: Equality and Bureaucracy," Aristotelian Society Supplementary Volume 82, no. 1 (2008), 139-160.

-The Imperative of Integration. (Princeton, N.J: Princeton University Press, 2010).

- "The Fundamental Disagreement between Luck Egalitarians and Relational Egalitarians," Canadian Fournal of Philosophy 36 (2012), 1-23.

-. "Equality," in The Oxford Handbook of Political Philosophy, ed. David Estlund (New York: Oxford University Press, 2012), 40-57.

Beitz, Charles. "Does Global Inequality Matter?," in Global fustice, ed. Thomas W. Pogge, (Oxford: Blackwell, 2001), 106-122.

Blake, Michael. "Distributive justice, State Coercion, and Autonomy," Philosophy \& Public Affairs 30, no. 3 (2002): 257-296.

Buchanan, James, “A Two-country Parable," in Fustice in Immigration, ed. Warren F. Schwartz, (Cambridge: Cambridge University Press, 1995), 63-66.

Freeman, Samuel. Fustice and the Social Contract: Essays on Rawlsian Political Philosophy. (New York: Oxford University Press, 2007).

Miller, David. "Equality and Justice," in Ideals of Equality, ed. Andrew Mason, (Oxford: Blackwell, 1998), 21-36.

—. National Responsibility and Global fustice. (Oxford: Oxford University Press, 2007).

${ }^{42}$ I am very grateful to Torin Alter for numerous useful discussions about the ideas presented here and for providing extensive feedback on several drafts of this essay. I also benefitted from helpful conversations with Cory Aragon and Max Cherem. 
—. "Territorial Rights: Concept and Justification," Political Studies 60, no. 2 (2012): 252-268. Nagel, Thomas. "The Problem of Global Justice," Philosophy \& Public Affairs 36, no. 2 (2008): 113-147.

Nath, Rekha. "Equal Standing in the Global Community," The Monist 94, no. 4 (2011): 593614.

Nine, Cara. Global fustice and Territory. (Oxford: Oxford University Press, 2012).

Norman, Richard. "The Social Basis of Equality," in Ideals of Equality, ed. Andrew Mason, (Oxford: Blackwell, 1998), 37-51.

O'Neill, Martin. "What Should Egalitarians Believe?," Philosophy \& Public Affairs 33, no. 2 (2005): 119-156.

Pogge, Thomas. Politics as Usual: What Lies Behind the Pro-poor Rhetoric. (Cambridge: Polity Press, 2010).

Rawls, John. The Law of Peoples. (Cambridge M.A: Harvard University Press, 1999).

Sangiovanni, Andrea. "Global Justice, Reciprocity, and the State," Philosophy \& Public Affairs 35, no. 1 (2007): 3-29.

Satz, Debra. "What is the Point of International Equality? Comments of Darrel Moellendorf's Cosmopolitan Fustice," International Fournal of Politics and Ethics 3, no. 2 (2003): 224-239.

Scanlon, T. M. "The Diversity of Objections to Inequality," in The Ideal of Equality, ed. Matthew Clayton and Andrew Williams (Basingstoke: Palgrave Macmillan, 2002), 41-59

Scheffler, Samuel. Equality and Tradition: Questions of Value in Moral and Political Theory. (Oxford: Oxford University Press, 2010).

Simmons, A. J., "On the Territorial Rights of States," Philosophical Issues 11 (2001): 300-326. Stilz, Anna. "Why Do States Have Territorial Rights?" International Theory 1, no. 2 (2009): 185213.

Wellman, Christopher Heath. "Immigration and Freedom of Association," Ethics 119, no. 1 (2008): 109-141. 